\title{
Pendampingan Warga Desa Sigedang, Wonosobo, Jawa Tengah tentang Dampak Negatif Perkawinan Sedarah dan Pola Konsumsi Makanan Rendah Nutrisi
}

\author{
Atik Triratnawati ${ }^{1}$, B.J. Istiti Kandarina ${ }^{2}$, Laksmi A. Savitri ${ }^{1}$, Suzie Handajani ${ }^{1}$, \\ Khidir M. Prawirosusanto ${ }^{1}$, Yauma Ayu Arista ${ }^{1}$ \\ ${ }^{1}$ Departemen Antropologi, Fakultas Ilmu Budaya, Universitas Gadjah Mada \\ ${ }^{2}$ Departemen Biostatistik Epidemiologi dan Kesehatan Populasi, FKKMK, UGM \\ Korespondensi: atik-tri@ugm.ac.id
}

\begin{abstract}
The Community service in Sigedang Village, Kejajar Subdistrict, Wonosobo Regency, Central Java was carried out in the form of mentoring and discussion about the problems of stunting toddlers who were found in the region. The target of the activity was Posyandu members, PKK and pengajian groups as well as the youth of the mosque. This community service is delivered through discussions about the dangers or negative impacts of management and consumption patterns of improper nutrition, blood marriages or marriages with lineages that are too close (endogamy), as well as the implications in living with stunting conditions. This activity is expected to help in reducing stunting cases in Sigedang village in the future.
\end{abstract}

Keywords: Sigedang, stunting, endogamy, nutrition

\begin{abstract}
Abstrak
Kegiatan PkM di Desa Sigedang, Kecamatan Kejajar, Kabupaten Wonosobo, Jawa Tengah dilakukan dalam bentuk pendampingan dan diskusi tentang permasalahan balita stunting dan orang cebol yang cukup banyak ditemukan di wilayah tersebut. Sasaran kegiatan adalah ibu-ibu anggota Posyandu, PKK, dan kelompok pengajian, serta para remaja masjid. Kegiatan pengabdian ini berupa diskusi dan rembuk tentang bahaya atau dampak negatif dari pengelolaan dan pola konsumsi makan yang tidak benar, perkawinan sedarah atau perkawinan dengan garis keturunan yang terlalu dekat, serta implikasi-implikasi dalam hidup dengan kondisi stunting dan cebol. Kegiatan ini diharapkan dapat ikut membantu pengurangan kasus stunting dan cebol di Desa Sigedang pada masa yang akan datang.
\end{abstract}

Kata kunci: Sigedang, cebol, endogami, nutrisi, keturunan

\section{Pendahuluan}

Sejumlah studi menunjukkan bahwa faktor-faktor penyebab stunting, orang dengan ukuran tinggi tubuh di bawah rata-rata orang umum, di antaranya adalah, pertama, rendahnya nutrisi asupan makanan yang dikonsumsi ibu hamil yang berpengaruh pada bayinya (Devi, 2010) atau yang biasa disebut dengan masalah gizi. Masalah ini memiliki implikasi biologis lebih jauh, antara lain, mengganggu tingkat pertumbuhan fisik, 
perkembangan kecerdasan otak, hingga rentannya sistem ketahanan tubuh seseorang sehingga mudah terjangkit sejumlah penyakit. Kedua, sejumlah penelitian menunjukkan adanya faktor lingkungan sosial-budaya, salah satunya adalah pola perkawinan sedarah. Perkawinan sedarah dapat memantik seseorang memiliki keturunan cebol/kuntet (Triratnawati, 2018; Effendi, 2012). Gejala berupa rendahnya asupan gizi dan juga kecenderungan perkawinan sedarah ini dapat diletakkan sebagai suatu gejala sosialekonomi suatu masyarakat, yang tidak lain merupakan gejala kemiskinan (Fikawati, Syafiq, dan Karima, 2015).

Di Jawa, utamanya Jawa Tengah, balita stunting dan orang cebol masih ditemukan pada masyarakat di Pegunungan Sindoro, dan Desa Sigedang, Kabupaten Wonosobo. Daerah ini merupakan wilayah dengan kasus stunting sejumlah 22 serta 14 orang cebol yang menonjol dari berbagai kelompok umur. Sejalan dengan karakterisasi sosial ekonomi di Wonosobo yang bukan wilayah miskin, Desa Sigedang memiliki angka pendapatan per kapita pada 2017 mencapai Rp 24,8 juta atau termasuk tingkat menengah jika dibandingkan dengan angka nasional. Faktor sosial-budaya dan keterbatasan akses kesehatan dipercaya menjadi penyebabnya. Arista (2018) menemukan, bahwa pola dominan perkawinan sesama warga desa (sedarah atau endogami desa) diduga sebagai penyumbang lahirnya orang kuntet di desa ini.

Studi kekerabatan di Jawa menyebutkan bahwa secara umum sistem kekerabatan dalam masyarakat Jawa ialah cognatic descent atau bilateral, yang idealnya perkawinan tidak dilakukan dengan kerabat dekat, baik dari garis ibu maupun garis bapak. Sekalipun telah terdapat larangan-larangan, dalam sistem sosial seperti ini perkawinan sedarah atau endogami desa dalam lingkaran keluarga batih masih mungkin terjadi. Arista (2018) juga menemukan bahwa orang cebol di Desa Sigedang yang awalnya berjumlah puluhan orang kini hanya tersisa tujuh orang. Ketujuh orang ini dalam kondisi memprihatinkan karena, selain tidak bekerja, mereka dalam kondisi sakit dan tidak terawat karena tidak tersentuh oleh pelayanan kesehatan yang memadai.

Selain itu, komunitas orang kuntet ternyata masih sangat kuat memegang tradisi dalam proses kehamilan hingga persalinan. Tabu terhadap jenis makanan dan perilaku tertentu masih berlaku bagi ibu hamil dengan tujuan memperlancar proses persalinan dan juga menghindari anak yang dilahirkan dalam kondisi sulit keluar maupun cacat. Tabu dan pantangan makanan serta perilaku selama kehamilan dipercaya tidak berakibat pada munculnya kasus cebol. Namun, masyarakat setempat percaya bahwa cebol muncul akibat keturunan atau dalam bahasa masyarakat setempat "ada jalurnya" (Triratnawati, 2018).

Alasan-alasan itulah yang membawa tim penulis melakukan kegiatan pendampingan warga di Sigedang dengan melakukan diskusi informal mengenai perkawinan endogami desa, termasuk di dalamnya soal pengaruh perkawinan sedarah atas munculnya kasus cebol. Topik lain yang tim penulis diskusikan ialah pentingnya ketercukupan nutrisi makanan, terutama tentang pola konsumsi makanan sehat bagi para ibu hamil untuk meningkatkan kesehatan ibu hamil dan anak-anaknya.

Dalam kegiatan ini, tim penulis melibatkan secara aktif para pamong desa, bidan, dan tokoh masyarakat setempat guna membantu kegiatan pengenalan pola makan yang baik dan sehat dalam perspektif kesehatan. Selain itu, tim penulis juga mendiskusikan cara mengoptimalkan potensi pangan setempat yang dapat dimanfaatkan untuk 
pemenuhan gizi warga desa. Kegiatan ini secara umum menyasar kepada para remaja (yang tergabung dalam kelompok remaja masjid), ibu-ibu usia reproduksi yang aktif dalam kegiatan-kegiatan di PAUD, Posyandu, PKK, dan kelompok pengajian setempat, serta para pamong desa dan posyandu.

\section{Pelaksanaan Kegiatan Pengabdian di Desa Sigedang}

Kegiatan PKM ini dipimpin oleh Dr. Atik Triratnawati dari Departemen Antropologi FIB UGM selaku ahli dalam bidang antropologi kesehatan. Dr. Atik dibantu oleh satu orang dokter ahli gizi klinik dari Fakultas Kedokteran, Kesehatan Masyarakat, dan Keperawatan (FKKMK UGM), Dr. rer.nat. dr. Istiti Kandarina. Mengenai masalah pemanfaatan lahan pangan, perilaku konsumsi remaja, dan masalah-masalah kekeluargaan serta remaja, Dr. Atik didukung oleh tim dengan beberapa keahlian, yaitu: (1) Dr. Laksmi A. Savitri, pakar dalam pemanfaatan sumber daya lokal dan kesehatan untuk konsumsi pangan; (2) Dr. Suzie Handajani, pemerhati budaya konsumsi dan keluarga; serta (3) Khidir M. Prawirosusanto, yang memiliki minat pada persoalan-persoalan kekerabatan. Kelima ahli ini dibantu oleh seorang mahasiswa yang melakukan penelitian skripsinya di Desa Sigedang, Yauma Ayu Arista. Ia berperan besar menghubungkan kami dengan warga setempat dan para pamong Desa Sigedang. Arista memberi sedikit gambaran masalah riil yang ada pada masyarakat Desa Sigedang.

Tabel 1. Jadwal Kegiatan Pengabdian kepada Masyarakat di Desa Sigedang

\begin{tabular}{|c|l|l|l|}
\hline No & \multicolumn{1}{|c|}{ Kegiatan } & \multicolumn{1}{|c|}{ Tanggal } & \multicolumn{1}{c|}{ Keterangan } \\
\hline 1 & $\begin{array}{l}\text { Diskusi dengan dua } \\
\text { kelompok Remaja Masjid } \\
2018\end{array}$ & $\begin{array}{l}\text { dan } 7 \text { Mei } \\
\text { risiko perkawinan dini untuk remaja } \\
\text { Rembuk warga dengan para pamong } \\
\text { atau perangkat Desa Sigedang }\end{array}$ \\
\hline 2 & $\begin{array}{l}\text { Diskusi dengan PAUD Al- } \\
\text { Hidayah di Desa Sigedang }\end{array}$ & 12 Mei 2018 & $\begin{array}{l}\text { Diskusi mengenai gizi dan balita sehat } \\
\text { kepada ibu-ibu usia produktif } \\
\text { Partisipan: anggota dan guru PAUD }\end{array}$ \\
\hline 4 & $\begin{array}{l}\text { Diskusi dengan satu } \\
\text { kelompok Remaja Masjid } \\
\text { di dua kelompok Posyandu/ } \\
\text { PKK di Kantor Desa } \\
\text { Sigedang }\end{array}$ & 13 Mei 2018 & $\begin{array}{l}\text { Diskusi mengenai pendidikan seks dan } \\
\text { risiko perkawinan dini untuk remaja }\end{array}$ \\
\hline
\end{tabular}

\section{Kesadaran Gizi dan Kebiasaan Makan: Bahaya 'Gula Biang' dan Sayuran Berpestisida}

Keberadaan anak dan orang dewasa yang mengalami pertumbuhan tinggi badan kurang sempurna di Sigedang, Wonosobo, bukanlah hal baru, sekalipun tidak banyak orang tahu. Penelusuran penulis di dunia maya menunjukkan liputan media yang pernah mengangkat masalah ini hanya sekali terjadi pada 10 Mei 2008, yakni oleh Liputan 
6. Tak heran jika fenomena pertumbuhan tinggi badan tak sempurna yang masih terjadi di Jawa merupakan temuan yang tidak biasa di tengah upaya Indonesia untuk menurunkan angka stunting hingga $2019^{2}$. Angka stunting di Indonesia, yaitu 35\%, sudah melampaui batas toleransi $20 \%$ atau seperlima dari keseluruhan jumlah balita ${ }^{3}$ sebagaimana yang telah ditetapkan oleh WHO.

Salah satu penyebab dari kondisi pertumbuhan tinggi badan tak sempurna ialah kebiasaan makan yang kurang memenuhi syarat gizi seimbang. Dr. B.J. Istiti Kandarina, ahli gizi UGM, menjelaskan bahwa kekurangan asupan makanan yang bergizi dan mengakibatkan pertumbuhan tak sempurna biasanya terjadi dalam waktu panjang, bahkan dapat dimulai dari kondisi ibu pra hamil ${ }^{4}$. Pantangan dan kebiasaan makan ibu hamil dapat mengakibatkan ketidakseimbangan gizi pada ibu, yang berakibat pada pertumbuhan janin. Kemudian, kondisi bayi lahir tidak didukung oleh pemberian ASI dan makanan yang berkualitas gizi baik akan mengkibatkan pertumbuhan tinggi badan dan perkembangan otak yang kurang optimal. Asumsi atas kebiasaan makan yang kurang memenuhi syarat kecukupan gizi telah melandasi kedatangan tim penulis untuk mengajak dan menemani warga Sigedang untuk urun rembuk soal kebiasaan makan dan kualitas makanan, serta dampaknya bagi pertumbuhan anak dan kesehatan ibu.

Pembicaraan atau rembuk mengenai kebiasaan makan dan dampaknya mendapat sambutan baik dari ibu-ibu anggota aktif posyandu di Gang Kemis dan ibu-ibu yang anaknya bersekolah di PAUD Al-Hidayah Desa Sigedang. Rembuk dimulai pada siang hari hingga sore menjelang Maghrib. Hal ini sengaja disesuaikan dengan waktu penyelenggaraan PAUD dan penimbangan bayi di posyandu agar ibu-ibu langsung dapat merefleksikan sendiri kondisi gizi anak melalui berat badan dan kebiasaan makan. Pada setiap pertemuan hadir sekitar tiga puluh ibu bersama balita usia 2-5 tahun. Kami memantik rembuk melalui cerita tentang makanan yang banyak mengandung gula, meskipun secara fisik bukan berbentuk gula, dan apa akibat makanan ini pada keseimbangan gizi anak serta ibu. Ide pembicaraan ini muncul dari cerita ibu-ibu PAUD yang menggambarkan kebiasaan masak mereka untuk makanan keluarga. Salah satu informasi yang cukup mengagetkan ialah penggunaan gula biang atau gula sintetis untuk memasak dan membuat minuman.

Menurut ibu-ibu dan juga sebagian besar warga Sigedang, makanan dan minuman jika tidak manis rasanya kurang mantap. Tim penulis merasakan sendiri bahwa masakan dan minuman di Sigedang kaya dengan rasa manis sehingga tidak mengherankan jika penggunaan gula untuk makanan dan minuman begitu tinggi. Namun, yang tidak terduga adalah penggunaan gula biang untuk memasak karena gula jenis ini biasanya digunakan untuk keperluan industri. Ketika tim penulis menanyakan seperti apa bentuk gula ini, salah seorang ibu bergegas pergi ke sebuah warung untuk menunjukkan sekantong gula biang yang biasa mereka gunakan. Rupanya, penggunaan gula biang adalah cara ibu-ibu untuk menyiasati biaya belanja. Mengingat konsumsi gula yang

1 https://www.liputan6.com/news/read/156398/dusun-sigedang-dusun-cebol

2 https://nasional.kompas.com/read/2017/10/03/18560031/pemerintah-optimistis-turunkanangka-stunting-hingga-2019

3 https://www.republika.co.id/berita/nasional/umum/18/01/24/p30s85396-who-78-jutabalita-di-indonesia-penderita-stunting

4 Presentasi B.J. Istiti Kandarina di Sigedang, 12 Mei 2018. 
tinggi, sedangkan harga gula mahal, satu kantong kecil sebesar kantong bumbu masak sekali pakai gula biang bermerek Mobil pabrikan kota Semarang menjadi penggantinya. Hanya dengan Rp 1.000,00 (seribu rupiah), gula biang ini dapat digunakan untuk memasak selama beberapa hari. Pemakaian gula biang sangat sedikit karena gula ini memberikan rasa manis sebanyak 300 kali dari rasa manis gula pasir sehingga cukup masuk akal jika sangat menghemat biaya belanja. Bubur kacang hijau yang terhidang ketika rembuk di PAUD pun terasa luar biasa manis karena menggunakan gula biang.

Kebiasaan makan warga Sigedang memakan masakan manis dan pedas, baik lauk maupun sayuran, membuat sebagian ibu-ibu mulai mengidentifikasi banyaknya orang tua yang kini mengidap penyakit kencing manis. Kondisi lahan yang hanya memungkinkan pertanian lahan kering menyebabkan warga Sigedang tidak dapat bertani padi sawah sehingga beras tetap harus dibeli. Kenyataan bahwa mereka menanam kentang pun tidak membuat orang Sigedang suka makan kentang dan mengombinasikan makanan pokoknya. Untuk makanan pokok, mereka tetap memilih membeli beras. Kombinasi antara kebiasaan makan nasi dan makanan atau minuman manis ini dalam jangka panjang memang dapat mengakibatkan penyakit diabetes, demikian umumnya diketahui.

Di sisi lain, tim penulis juga tidak menemukan anak-anak dan orang dewasa yang mengalami obesitas. Diduga, kegiatan ibu-ibu yang secara fisik cukup berat di ladang pertanian kemungkinan besar menyeimbangkan kalori yang masuk dari asupan gula dan kalori yang dikeluarkan. Salah satu gambaran kerja fisik yang berat misalnya adalah yang dilakukan oleh Bu Umi, istri Lurah Sigedang. Ia sudah memiliki seorang cucu dan masih terus bekerja setiap hari di ladangnya. Ketika ia harus menjaga cucu—anak perempuannya bekerja di luar desa—bu lurah menggendong sang cucu di punggung, baik ketika bekerja ladang maupun di rumah. Desa Sigedang yang berbukit-bukit dan letak rumah dan ladang jauh menyebabkan kegiatan fisik harian yang cukup menguras tenaga. Apalagi bagi perempuan yang harus menggendong anak sambil berjalan naikturun dari rumah ke ladang dan menundukkan badan mencabuti rumput pengganggu tanaman kentang atau wortel mereka dari pagi hingga siang hari. Namun, ketika usia menua dan kegiatan fisik berkurang, asupan gula dapat menjadi cikal bakal diabetes.

Usaha pertanian hortikultura menjadi andalan nafkah warga Sigedang dan sudah berlangsung selama puluhan tahun. Selama puluhan tahun itu pula, petani perempuan dan laki-laki menggunakan pestisida dalam usaha pertaniannya. Saat bertani, seringkali warga juga menggendong anak mereka. Kesadaran atas bahaya pestisida terhadap tubuh anak ternyata terartikulasi baik oleh ibu-ibu dan bapak-bapak di Sigedang. Oleh sebab itu, ibu-ibu di posyandu mengaku bahwa mereka tidak pernah atau jarang menggunakan kentang dan wortel atau sayuran apa pun yang mereka tanam di ladang untuk memasak makanan di rumah karena sayurannya berpestisida. Mereka lebih memilih membeli sayur di tukang sayur meski mereka pun mengetahui bahwa sayur yang mereka beli tersebut belum tentu tidak berpestisida pula. Oleh sebab itu, tim penulis melihat banyak pot-pot kecil daun bawang, sawi, dan sayuran lain yang ditanam di depan rumah. Sayuran dalam pot ini dimungkinkan bertujuan untuk konsumsi rumah tangga demi menghindari sayuran berpestisida dari ladang.

Kekhawatiran ini mendorong tim penulis agar pada waktu mendatang dapat berbagi informasi tentang akibat dari paparan pestisida dan upaya menghindarinya. Penting untuk dijadikan catatan bahwa tidak semua warga Sigedang bertaraf hidup 
baik seperti yang digambarkan oleh motor dan mobil yang terparkir hampir di setiap rumah. Mereka yang menjadi buruh tani dan memiliki penghasilan kecil kemungkinan menjadi bagian dari siklus kemunculan anak dengan tinggi badan tak sempurna akibat kemiskinan. Perhatian pada perbedaan tingkat sosial ekonomi di antara warga Sigedang dan kaitannya pada kemunculan stunting dan cebol menjadi catatan penulis untuk melanjutkan kegiatan ke depannya.

\section{Masalah Gizi pada Anak}

Sehubungan dengan hal itu, jika melihat kembali pada masa lalu, kebutuhan gizi manusia dikenal dengan slogan 4 sehat 5 sempurna. Slogan tersebut tidak lagi sesuai dengan dinamika masyarakat serta kebutuhan akan gizinya. Oleh karena itu, saat ini slogan tersebut telah diganti dengan istilah "gizi seimbang". Gizi seimbang memiliki empat pilar: konsumsi makanan yang beragam dan berjumlah seimbang, biasakan perilaku hidup sehat, melakukan aktivitas fisik seperti olah raga, dan mempertahankan berat badan.

Gizi seimbang pada masa kanak-kanak menjadi hal yang sangat penting sebab masa itu merupakan masa emas ketika otak dan pertumbuhan badan lainnya dimulai. Apabila masa itu terlewat, masa-masa perkembangan berikutnya akan terganggu. Dalam makanan yang beragam harus terkandung unsur makanan pokok, sayuran, buah, susu serta protein nabati dan hewani. Protein nabati terdapat di dalam kacang-kacangan, sementara protein hewani terdapat di dalam ikan, daging, dan telur. Lauk pauk yang dikonsumsi anak-anak harus diganti setiap hari agar mereka tidak bosan dan lauk harus mengandung protein tinggi. Gizi yang dibutuhkan tidaklah harus berharga mahal, tetapi ibu harus paham akan gizi dan pandai memilih zat gizi yang tidak mahal. Empat pilar gizi seimbang di atas tidak hanya terkait dengan makanan ataupun minuman yang harus dikonsumsi. Aktivitas tubuh pun harus diperhatikan sebagai aspek pendukung pertumbuhan.

Di samping itu, perilaku hidup sehat juga penting untuk diperhatikan. Jangan sampai ibu-ibu membiarkan anak-anaknya bermain sehari penuh dengan alasan "yang penting anak tidak menangis", sementara anak-anak dibiarkan tidak makan-minum, tidak mandi, dan tidak berganti pakaian. Anak yang aktif dan hidup dengan bersih termasuk dalam perilaku hidup sehat. Salah satu contoh yang kurang baik adalah banyak perilaku ibu yang tidak mengganti popok bayi dan anaknya karena anak tidak menangis atau tidak meminta diganti. Para orang tua harus mengerti kapan mengganti popok tanpa perlu diminta oleh anak. Hidup sehat akan memungkinkan anak tumbuh dan berkembang dengan baik. Hidup tidak sehat akan menimbulkan gizi buruk yang berakibat anak rentan terkena penyakit.

Tumbuh kembang anak tidak hanya berarti anak tumbuh dengan gemuk dan tinggi, tetapi mereka tumbuh dengan normal sesuai umurnya. Olahraga menjadi aktivitas penting yang harus dilakukan manusia berapapun umur mereka. Olahraga harus rutin dilakukan dan disesuaikan dengan usia. Untuk orang dewasa, olahraga dilakukan sedikitnya 30 menit setiap hari dan sebaiknya dilakukan 3-5 kali setiap minggu. Untuk anak-anak, kegiatan olahraga dapat disesuaikan dengan usia dan kegiatannya. Aktivitas fisik diperlukan agar otot dan sendi bergerak sehingga tidak kaku serta melancarkan peredaran darah. Anak-anak dapat melakukan aktivitas fisik seperti berlari-lari, berjalan- 
jalan di sekitar rumah, dan jangan dibiarkan hanya tidur atau duduk asalkan tidak menangis. Semua anggota tubuh anak harus digerakkan agar otot dapat berfungsi optimal.

Seorang bayi, anak-anak, atau pun orang dewasa penting untuk memantau berat badannya setiap bulan. Ibu-ibu yang memiliki balita pasti memiliki Kartu Menuju Sehat (KMS). KMS harus dibawa saat penimbangan di Posyandu dan kartu tersebut akan diisi oleh petugas. Ibu-ibu hendaknya memperhatikan grafik berada di garis merah, kuning, atau hijau. Semua warna mengandung arti. Para ahli gizi telah mengembangkan ukuran untuk memantau berat badan tersebut, yaitu IMT (indeks massa tubuh): berat badan (kg) dibagi dengan tinggi badan (m) dikali dengan tinggi badan (m). Berat badan penting diperhatikan dan berat badan normal harus selalu dipertahankan karena berat badan kurang maupun berlebih akan rentan terhadap penyakit.

Di Desa Sigedang tumbuh beraneka sayuran dan buah yang harus dimanfaatkan dengan baik. Selama ini, masyarakat kurang memperhatikan hal tersebut. Sayuran yang beraneka menjadi sumber lauk nabati. Ibu-ibu harus mampu mengolah sayuran dengan baik. Sayuran harus dicuci sebelum dipotong dan dimasak. Agar sayuran tetap berwarna hijau, waktu memasak tidak boleh terlalu lama. Kemudian, garam sebaiknya dimasukkan saat sayur sudah diangkat dari kompor sebab garam yodium dapat rusak apabila dimasak terlalu panas. Ibu-ibu harus memilih garam yodium sebab daerah pegunungan seperti Desa Sigedang rawan untuk kekurangan yodium. Di samping itu, kebiasaan yang salah yang selama ini sering dilakukan oleh ibu-ibu adalah anak sekolah diberi uang saku namun tidak diberi sarapan. Membiasakan makan sarapan sebelum sekolah sangat baik untuk kesehatan anak. Anak juga harus diberi minum air mineral dan jangan terlalu sering diberi minuman berwarna yang tidak sehat serta mengandung gula atau pewarna tekstil. Anak-anak harus dibatasi makanannya dari rasa asin, manis, dan berlemak sebab jika terlalu banyak akan berisiko terhadap penyakit.

Secara sederhana, anak dengan asupan gizi cukup akan memiliki perkembangan tubuh yang normal. Sebaliknya, mereka yang kekurangan gizi akan berdampak pada perkembangan secara keseluruhan. Dalam jangka pendek akan muncul gangguan pada janin dan anak usia dini. Hal itu ditandai dengan anak mengalami gangguan perkembangan otak, gangguan pertumbuhan, dan gangguan metabolik. Berikutnya, kemampuan kognitif anak pendek, stunting, bahkan muncul diabetes, hipertensi, obesitas, dan lain-lain. Dalam jangka panjang, ibu bisa menjadi pendek dan berat badan ibu pra hamil rendah. Oleh karena itu, ibu-ibu yang memiliki balita harus benar-benar memperhatikan asupan makanan dan kebutuhan gizi mereka sebab pada masa itulah otak dan kognitif anak terbentuk. Ibu harus mampu menyipakan makanan tidak hanya kebersihannya, tetapi juga variasi dan tampilan agar anak tidak bosan. Memanfaatkan sumber pangan lokal menjadi suatu keharusan. Pengetahuan akan gizi harus dimiliki oleh ibu-ibu, baik melalui cara formal maupun informal.

\section{Tentang Seks dan Perkawinan bagi Remaja}

Pada 6 dan 13 Mei 2018, tim penulis bertemu dengan beberapa kelompok remaja dari beberapa gang yang ada di Desa Sigedang. Setiap gang atau blok desa memiliki satu musala atau masjid yang didalamnya terdapat kelompok-kelompok Remaja Masjid. 
Pada dua hari tersebut, tim penulis mengajak mereka untuk berdiskusi tentang masalah pendidikan seks dan perkawinan dini bagi remaja. Dua kegiatan ini dilakukan pada pukul 14.00 WIB, yakni pada waktu-waktu setelah pulang sekolah atau pulang bekerja di ladang milik orang tua mereka. Sejak awal kedatangan ke pertemuan, mereka terlihat memiliki rasa ingin tahu yang kuat, namun terbalut oleh rasa enggan dan malu. Namun, seiring berjalannya obrolan kami, mereka pun memenuhi ruangan yang disediakan untuk berdiskusi dan berpartisipasi secara aktif.

Diskusi ini dibuka melalui pengantar singkat dari Dr. Atik tentang pentingnya memahami seksualitas dan perkawinan bagi remaja. Anak muda saat ini menghadapi tantangan yang berbeda dengan zaman para orang tua mereka dahulu. Saat ini, mereka diminta menempuh waktu sekolah yang lebih panjang dari generasi sebelumnya. Namun sebaliknya, periode kematangan biologis mereka datang lebih awal, terutama para remaja wanita. Contoh nyatanya ialah datangnya menstruasi remaja saat ini lebih cepat dari generasi ibu dan nenek mereka. Hal ini membawa periode tekanan seksual (sexual tension) yang lebih panjang karena mereka diminta untuk menunda pernikahan setelah menyelesaikan sekolah.

Diskusi kemudian dilanjutkan dengan pertanyaan pembuka: Apa yang ingin dibahas dalam diskusi tentang pendidikan seks bagi remaja Sigedang? Secara sekilas, remaja lakilaki terlihat lebih berani untuk memberi komentar. Sementara itu, remaja perempuan masih banyak terdiam dan sibuk membaca situasi. Pertanyaan yang menjadi pembuka sesi tanya jawab ini menjadi penentu wacana selanjutnya. Pertanyaan selanjutnya datang dari seorang pemuda yang ingin tahu bagaimana caranya agar perempuan-perempuan remaja di Sigedang tetap "terjaga keperawanannya”.

Pertanyaan soal keperawanan ini memang kontroversial bila dibawa ke ranah diskursus akademis. Namun, dalam konteks pemuda tanggung yang mungkin sebentar lagi diminta memutuskan apakah akan melanjutkan pendidikan atau bertani di Sigedang (angka merantau di Sigedang sangat kecil), hal ini dapat sedikit dipahami. Dari pertanyaan ini, diskusi bergulir dengan lontaran pertanyaan-pertanyaan lain: Mengapa hanya kepada perempuan soal keperawanan dibahas? Bagaimana dengan keperjakaan? Apakah laki-laki tidak perlu perjaka? Pendidikan seks rupanya mau tidak mau harus bertautan dengan pendidikan gender. Tim penulis pun menggiring diskusi terbuka dan dalam kemasan obrolan ringan yang menuju ke sana.

Akhirnya, para remaja perempuan pun mulai berkontribusi dalam diskusi ini. Mereka menunjukkan sikap bahwa mereka dapat merasakan ketidakadilan gender dalam wacana pendidikan seks yang mereka terima - terutama mengenai persoalan keperawanan ini sebab keperawanan ini mengarah pada masalah moral dari nilai-nilai agama yang diyakini selama ini sebagai acuan yang baku, yang tidak dapat digugat kebenaran moralnya.

Secara sepintas, sesi diskusi ini menjadi "sesi curhat" tentang ketidakadilan sosial yang dialami perempuan dalam wacana seksualitas sehari-hari. Seorang remaja perempuan akhirnya mengacungkan tangan dan mengatakan bahwa dia adalah aktivis GenRe (Generasi Berencana) di sekolahnya serta menjadi duta di tingkat kecamatan. GenRe merupakan program pemerintah untuk meningkatkan pengetahuan anak muda mengenai kesehatan reproduksi. Dia memahami banyak persoalan reproduksi dan alat-alat kontrasepsi. Sayangnya, pengetahuan ini hanya berani disampaikan dengan 
setengah berbisik kepada sesama perempuan di sekitarnya. Pengetahuannya yang luas tentang kesehatan reproduksi ini harus dihadapkan pada pandangan konvensional rekan-rekannya, terutama rekan laki-laki, yang belum beranjak dari pikiran-pikiran lama bahwa seksualitas itu milik laki-kali. Perempuan diharapkan lugu dan tidak tahu apa-apa, yang menjadi indikator keperawanannya. Itu sebabnya, aktivis GenRe ini berbicara pelan-pelan ketika hendak menjelaskan tentang alat kontrasepsi kondom kepada perempuan-perempuan remaja lainnya yang duduk bersila di sekitarnya. Seperti ada rasa jengah jika rekan laki-laki yang duduk di seberangnya mendengar pembicaraan ini. Sementara itu, kelompok laki-laki remaja di seberang ruangan tertawa dan masih menganggap bahwa perbincangan tersebut adalah hal yang saru. Mereka menganggap dapat memecahkan rasa malu terhadap topik yang sensitif ini dengan tertawa.

Perlu diketahui bahwa desa Sidegang ini adalah desa yang sudah sadar teknologi dengan tersedianya internet untuk perangkat desa. Sekilas terlihat bahwa para remaja juga memegang ponsel pintar. Hal ini menunjukkan bahwa isolasi lokasi geografis tidak sepenuhnya dapat dijadikan indikator terkurungnya suatu tempat terhadap dunia luar. Dunia maya dapat membuat jaringan digital yang membuka koneksi suatu lokasi dengan dunia luar dan mereka pun sudah sangat akrab dengan dunia internet.

Kondisi di atas, jika dihubungkan dengan laporan PKM ini, mengindikasikan bahwa sudah pasti remaja Sigedang juga sedikit banyak telah terpapar informasi tentang seks dan seksualitas melalui internet. Pertanyaan selanjutnya: Seberapa banyak mereka tahu dan bagaimana mereka mengambil ilmu serta hikmah dari apa yang mereka tahu? Teknologi internet yang tertaut ke dalam ponsel pintar menjadikan segala hiburan dan informasi menjadi konsumsi pada ranah privat dan personalized. Hal ini berbeda dengan era televisi dan koran dengan hiburan serta informasinya yang disajikan secara massal dan publik. Sifat publik ini membuat informasi di media dapat didiskusikan secara terbuka di luar media. Berkebalikan dengan kondisi tersebut, internet membuat penggunanya tahu lebih banyak, tetapi tidak semua orang mengerti apa yang harus diperbuat dengan gempuran pengetahuan itu. Reaksi dan respons terhadap informasi digital itu juga dilakukan pada ranah privat di dalam media digital itu, misalnya dengan fitur like, subscribe, dan comment, yang kemudian di dunia offline tidak dibahas kembali, apalagi jika topik pembahasannya adalah seks dan seksualitas.

Remaja Sigedang dimungkinkan terpapar informasi dari dunia maya, tetapi karena sifat internet yang privat dan wacana seks yang masih dianggap tabu, informasi itu pun tidak pernah diolah atau didiskusikan secara terbuka dengan orang lain. Akhirnya, mereka banyak tahu namun salah dalam mengambil hikmah dari apa yang mereka ketahui itu. Dengan kata lain, mereka memiliki pengetahuan namun belum dapat mengolahnya menjadi sebuah ilmu. Hal ini menjelaskan bahwa remaja laki-laki Sigedang masih mempersoalkan perihal "keperawanan”, bukan "keperjakaan”. Hal ini dapat terjadi karena informasi baru yang diperoleh dari internet dimaknai dan diambil hikmahnya dengan menggunakan ideologi lama.

\section{Penutup}

Kegiatan Pengabdian Kepada Masyarakat ini berusaha menyasar ibu-ibu anggota Posyandu, PKK, dan kelompok pengajian, serta para remaja masjid di Desa Sigedang, 
Kecamatan Kejajar, Kabupaten Wonosobo, Jawa Tengah. Kegiatan ini dilaksanakan dalam kurun enam hari dan mengambil hari di antara bulan Mei-Juni 2018, yakni menyesuaikan dengan jadwal posyandu setempat. Kegiatan pengabdian ini berupa diskusi dan rembuk bersama warga (ibu-ibu dan remaja) tentang bahaya atau dampak negatif dari pengelolaan dan pola konsumsi makan yang tidak benar serta perkawinan sedarah atau perkawinan dengan garis keturunan yang terlalu dekat. Kedua hal ini yang diusung dan menjadi penekanan agar maraknya kasus stunting dan cebol di Desa Sigedang, Wonosobo berkurang pada masa yang akan datang. Selain itu, melalui pertemuanpertemuan itu, penulis mencoba menggali informasi dengan berdialog guna menelusuri implikasi-implikasi dalam kehidupan seseorang dengan kondisi stunting dan cebol. 